\title{
Design of Integrated Electrochromic-Photovoltaic Technology for Smart Windows to Improve Building Performance and Energy Efficiency: A Material Approach
}

\author{
Laurentius K. Hendinata ${ }^{1}$ *, Ahmad I. R. Fikri ${ }^{1}$, Michael A. Suprapto ${ }^{1}$ \\ ${ }^{1}$ Department of Nuclear Engineering and Engineering Physics, Faculty of Engineering, Universitas Gadjah Mada, Jl. Grafika \\ No. 2, Senolowo, Sinduadi, Kec. Mlati, Kabupaten Sleman, Daerah Istimewa Yogyakarta 55281, Indonesia \\ *Corresponding Author: kevinhendinata@mail.ugm.ac.id
}

\section{Article History}

Received 17 June 2021

Accepted 13 October 2021

Available 27 February 2022

\begin{abstract}
Energy and climate problems that occur encourage the intensification of energy use efficiency, one of which is in buildings. The building sector is the largest contributor to energy consumption when compared to other sectors due to the need for comfort in life, including to regulate air temperature, ventilation and artificial lighting. Window innovation as a building component leads to adaptive smart windows technology that has energy saving features. The use of these windows is attractive because they are designed to adapt to changing environmental conditions to minimize large heat losses by adjusting their transmissivity and conductivity. Various types of smart windows have developed, one of which is electrochromic technology as dynamic glass technology, which has been widely used as smart windows in commercial buildings. Several studies have shown that its use in buildings has been shown to save energy consumption in buildings through the heating, ventilating and air conditioning (HVAC) as well as lighting aspects. However, in today's technology, its performance still requires external power to adjust their optical conditions. Therefore, the innovation in developing electrochromic smart windows technology that is integrated with photovoltaic technology is an interesting thing to do, because it provides a greater energy advantage than electrochromic windows. The combination of the electrochromic solution with semi-transparent silicon thin film solar cell ( $\mathrm{Si}$-TFSC) placed on a glass substrate provides promising optical performance and energy benefits. The integration of electrochromic and photovoltaic devices provides better efficiency in energy saving, because photovoltaic and electrochromic devices can achieve electrochromic layer discoloration without an external power source. Given the photoelectric modulation and optical properties of electrochromic photovoltaic windows that can function as solar cell modules as well as self-powered smart windows, this technology provides significant energy savings while providing energy. Its application in buildings, to improve device performance, the control system can be applied by adjusting environmental conditions according to the sensor system readings to obtain better device performance.
\end{abstract}

\section{Keywords:}

smart windows, electrochromic, photovoltaic, Si-TFSC, optical performance, energy saving potential 


\section{Introduction}

Energy and climate change are problems that concern the world today. Energy demand is expected to increase as a consequence of population and economic growth so that providing sufficient and affordable energy is required to increase human welfare and living standards (Türkoğlu \& Kardogan, 2017). One of the problems in the energy sector that is currently of concern is energy efficiency, including in the building. The global building sector is responsible for $30 \%$ of final energy consumption and more than 55\% of electricity demand (Corrado, 2018; IEA, 2019). Thus, energy consumption in the building sector, especially in office and commercial buildings, is the highest when compared to various other sectors (Gul \& Patidar, 2015). The high level of energy consumption in buildings is caused by the need to improve the quality of living comfort, which includes regulating air temperature, ventilation and lighting, which results in the highest energy consumption in buildings compared to other sectors (Ke et al., 2019; Park, 2019).

To achieve a significant reduction in energy consumption in buildings, it is necessary to adjust the architecture of the building, use energy-efficient technologies and reduce energy consumption in its operation phase (Corrado, 2018; Gul \& Patidar, 2015). However, to achieve significant reductions in energy consumption in buildings other than standard energy efficiency methods, proven renewable energy technologies must be applied and integrated with passive buildings (Chel \& Kaushik, 2018; Chwieduk, 2003). Based on several studies in the field of building physics, windows as a building component can be developed as an energy-saving technology with adaptive features that can adapt to changing environmental conditions so as to minimize significant thermal losses by optimizing natural lighting (Nunes et al., 2019). These systems, together with lighting control systems and air conditioning, enable significant energy and environmental savings, as well as ensure better thermal and visual comfort for occupants (Casini, 2014).

In recent years, adaptive window innovation has made rapid progress in creating a comfortable life with the development of smart window technology, both passive and active control (Casini, 2014). This window is able to control the transmission of solar radiation into the building by turning it transparent or opaque by adjusting the intensity of sunlight that can enter the building (Balakrishnan \& Pattathil, 2019). Among the various types of smart window technologies, such as chromogenic windows (thermochromic, photochromic, gasochromic and electrochromic), polymer-dispersed liquid crystals (PDLC) or suspended particle devices (SPD), electrochromic windows are the most interesting technology that has undergone continuous evolution for many years and are in great demand in the market (Ke et al., 2019). The electrochromic window is attracting attention because it has dynamic modulation over a wide spectrum range and can be controlled by the user to meet personal preferences (Y. Wang et al., 2016). Although these windows can save energy consumption in buildings very effectively, electrochromic windows actually require energy to operate, because electrochromic windows operate when given a voltage difference between the conductive layers which causes ions to move from the accumulated layer to the electrochromic layer to change their optical properties (Balakrishnan \& Pattathil, 2019; Ke et al., 2019). On the other hand, windows have the potential to obtain solar radiation supply in high intensity. Thus, seeing the potential for greater energy savings from electrochromic windows, it is interesting to develop the integration of electrochromic and photovoltaic technology because this development will be able to increase energy efficiency in buildings, while increasing building performance, and maximizing the potential of solar energy. There are several literatures that have reported the combination of these two technologies. The results obtained also tend to be low and actually require high material and fabrication costs (Arifin et al., 2017; Fernandes \& de Zea Bermudez, 2021; Zhang et al., 2019). Therefore, this research was conducted to obtain a comprehensive design opportunity of the electrochromic-photovoltaic configuration, especially in terms of material selection which will be used as smart windows to improve building performance and energy efficiency. 


\section{Method}

This research was carried out by designing an integrated electrochromic-photovoltaic system configuration based on sources from the literature and looking for opportunities to integrate the two systems, including choosing which combination of technologies would be most beneficial. Not much literature discusses the combination of these two technologies, especially the design reported in the literature is still very early and limited to certain materials, although in fact many other electrochromic materials also have the potential to be combined with photovoltaics. This study was conducted to review the existing combinations and find the most superior combination. In addition, a comparison of electrochromic materials without photovoltaic was also carried out to provide opportunities for combining with photovoltaic. The performance reviewed in this comparison is represented by its optical performance and energy saving potential. This is because as a dynamic smart window that can change the clarity of the glass, optical performance becomes important, especially in windows represented by changes in transmittance. In addition, the potential for energy savings is another key feature of using smart windows, and the addition of photovoltaics should also provide a greater potential for energy benefits. At the end of this study, recommendations are also given for the application of a control system strategy for electrochromic-photovoltaic devices if applied to buildings to obtain optimal benefits.

\section{Electrochromic and Photovoltaic Technology}

\subsection{Electrochromic Technology}

Electrochromic technology is defined as the optical transfer of a material to a bleached, colored or intermediate state by inserting or releasing multiple ions and electrons under a given voltage (Dao \& Nguyen, 1989). In general, an electrochromic device consists of a multilayer structure (electrochromic material, an electrolyte and an ion storage layer) flanked by two transparent conductor (TCO transparent conductive oxides), which can modulate the optical properties reversibly upon application of an electric potential (Ke et al., 2019), as shown in Figure 1. This configuration is similar to a battery configuration so that a redox electrochemical reaction (reduction-oxidation) can occur inside the smart window (Heckner \& Kraft, 2002).

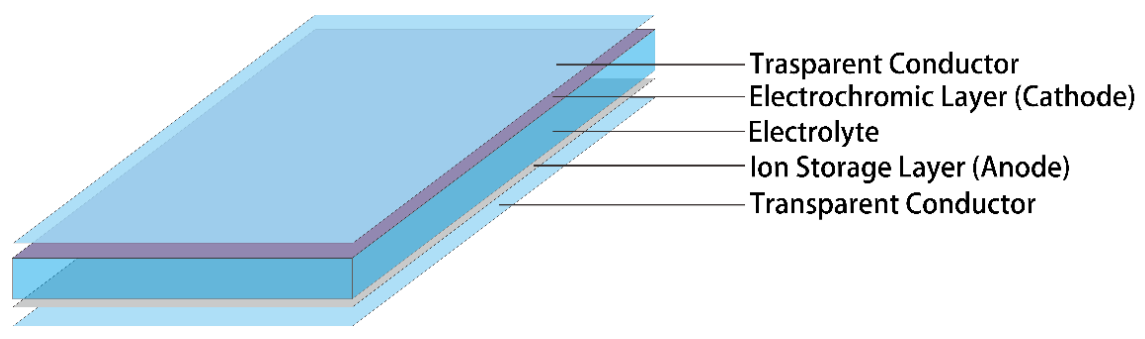

Figure 1. Electrochromic device configuration.

The most widely used transparent conductor or transparent conducting electrode (TCE) coatings in electrochromic configurations are indium tin oxide (ITO) coated glass or fluorine-doped tin oxide (FTO) coated glass. This is due to the high transmittance and high electronic conductivity of these two materials (Balakrishnan \& Pattathil, 2019; Ke et al., 2019). Meanwhile, for the electrochromic layer material, several types of materials can be used, including inorganic metal oxides $\left(\mathrm{WO}_{3}, \mathrm{NiO}, \mathrm{Nb}_{2} \mathrm{O}_{5}\right.$, $\mathrm{TiO}_{2}, \mathrm{~V}_{2} \mathrm{O}_{5}, \mathrm{Ta}_{2} \mathrm{O}_{5}, \mathrm{MoO}_{3}$, etc.) (Granqvist, 2014; Ke et al., 2019; Mortimer, 2011), Prussian blue, conductive polymers (poly-3,4-ethylenedioxythiophene (PEDOT), polyaniline (PANI), polypyrrole, etc.) (Cai et al., 2017; Ke et al., 2019), viologens and transition metal coordination complexes (Ke et al., 2019; Mortimer, 2011). While in the ion storage layer, $\mathrm{NiO}, \mathrm{CeO}_{2}$ and $\mathrm{IrO}_{2}$ materials are often used (Choi et al., 2018; Mortimer, 2011).

As a window technology, it is important to review the optical and thermal parameters. In some electrochromic windows, the optical and thermal parameters are represented by VT/VLT (Visible Transmittance/Visible Light Transmittance), UV Transmittance, SHGC (Solar Heat Gain Coefficient) 
and UV Transmittance. In general, the characteristics of the electrochromic window are shown in Table 1 .

Table 1. Electrochromic windows characteristics (Casini, 2014; Sbar et al., 2012).

\begin{tabular}{lr}
\hline Characteristics & Performance $(\%)$ \\
\hline VLT (Clear State) & 60.00 \\
VLT (Dark State) & 1.00 \\
SHGC (Clear State) & 0.46 \\
SHGC (Dark State) & 0.06 \\
UV Transmittance (Clear State) & 0.40 \\
UV Transmittance (Dark State) & 0.00 \\
\hline
\end{tabular}

The characteristics of the electrochromic window not only refer to two conditions: a clear state and a dark state, but the state can change continuously depending on the electrical input in a certain gradient. This is one of the characteristics of the electrochromic window that makes it superior to other smart windows, such as PDLC and SPD which only have two states without gradients, or compared to other chromogenic (photochromic and thermochromic) windows which are passive and cannot be controlled.

\subsection{Photovoltaic Technology: Semi-Transparent Thin Film Silicon Solar Cell (Si-TFSC)}

As an energy conversion element, solar cells are elements that convert solar energy into electricity. In terms of structure, a solar cell is a connecting device obtained by electronically placing two different materials together with a thin electronic barrier between them to separate the charges (Chopra et al., 2004). In this structural arrangement, when a photon with sufficient energy strikes a p-type and n-type junction, an electron is expelled by obtaining energy from the striking photon and moves from one layer to another creating electrons and holes in a power-generating process (Sharma et al., 2015).

Basically, solar cells can be classified into first generation cells (also called conventional, traditional or wafer-based cells) which are made of polycrystalline and monocrystalline silicon, second generation cells (also called thin film solar cells) which include amorphous silicon cells, cadmium telluride (CdTe) and copper indium gallium selenide (CIGS) and third generation solar cells (often described as emerging photovoltaics) which include nanocrystalline based solar cells, polymer based solar cells, dyesensitized solar cells, perovskite based solar cells and concentrated solar cells (Askari et al., 2015; Salve, 2020; Sharma et al., 2015). Of the other types of thin film solar cells, amorphous silicon (a-Si) is interesting to discuss because it is the most well-developed thin film technology that has been on the market for over 15 years (Askari et al., 2015). Besides, amorphous silicon (a-Si) solar cells can be produced at low processing temperatures, enabling the use of a wide variety of low-cost substrates, polymers and other flexible substrates (Sharma et al., 2015).

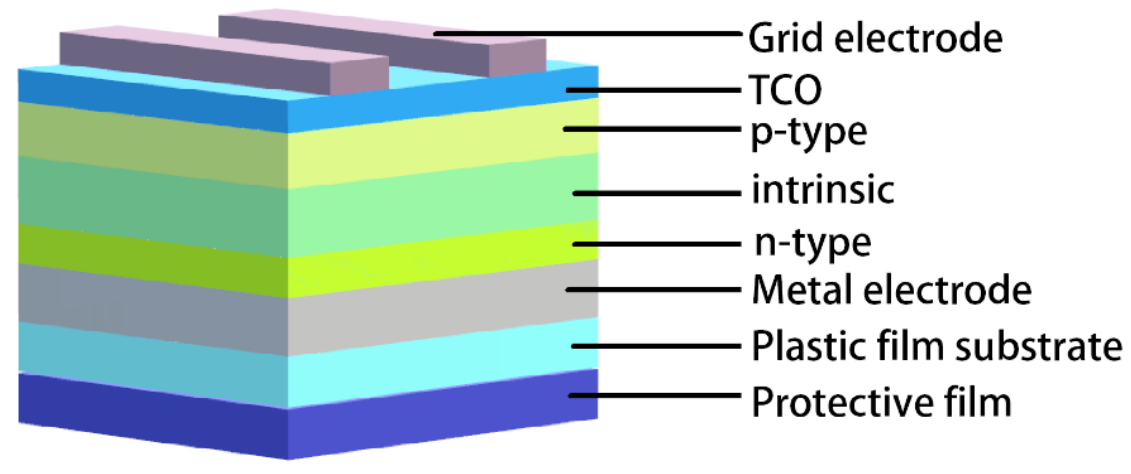

Figure 2. Amorphous silicon solar cell structure configuration (Adapted from Fraas, 2014).

However, the efficiency of these amorphous silicon type solar panels tends to be low at 4-8\% partly due to the Staebler-Wronski effect, which manifests itself in the first hours when the panels are exposed 
to sunlight, and results in a decrease in the energy yield of the amorphous silicon panels (Askari et al., 2015; Sharma et al., 2015).

\section{Integrated Electrochromic-Photovoltaic Technology}

The integrated electrochromic-photovoltaic technology system will combine the use of electrochromic and photovoltaic technology in one smart window system. Basically, this combination requires photovoltaic which has transparent/semitransparent properties, one of which is dye-sensitized solar cell (DSSC) and thin film solar cell (TFSC). There is some literature that says that the combination of the two photovoltaic technologies with electrochromic layers is possible and interesting to make, with variations of photovoltaic materials and technologies as well as variations of electrochromic coating materials. The combinations made are quite diverse, as shown in Table 2.

Table 2. Various photovoltaic technologies are combined with electrochromic devices.

\begin{tabular}{|c|c|c|c|c|c|}
\hline PV Type & EC Material & EC Material & Efficiency & $\begin{array}{c}\text { Transmittance } \\
\text { Change }(\Delta \mathrm{T})\end{array}$ & Reference \\
\hline \multirow{3}{*}{$\begin{array}{c}\text { Dye- } \\
\text { Sensitized } \\
\text { Solar Cell } \\
\text { (DSSC) }\end{array}$} & $\mathrm{TiO}_{2}$ & $\mathrm{WO}_{3}$ & $2.9 \%$ & $34.2 \%$ & (Ahn et al., 2007) \\
\hline & $\mathrm{TiO}_{2}$ & Viologen & $1.1 \%$ & $13.3 \%$ & (Santa-Nokki et al., 2007) \\
\hline & $\mathrm{TiO}_{2}$ & PProDot-Et 2 & - & $14.1 \%$ & (Hsu et al., 2008) \\
\hline \multirow{3}{*}{$\begin{array}{l}\text { Thin Film } \\
\text { Solar Cell - } \\
\text { (TFSC) }\end{array}$} & a-Si: H & $\mathrm{WO}_{3}$ & $1.0 \%$ & $43.0 \%$ & (Gao et al., 1999) \\
\hline & a-Si: $\mathrm{H}$ & $\mathrm{WO}_{3}$ & - & $40.0 \%$ & (Bechinger et al., 1998) \\
\hline & a-Si: H & $\begin{array}{c}\text { Polyaniline } \\
(\text { PANI) + PSS }\end{array}$ & - & $34.0 \%$ & (Huang et al., 2016) \\
\hline
\end{tabular}

Looking at the various configurations offered by several literatures, the configuration using $\mathrm{WO}_{3}$-based electrochromics and thin film solar cells is an interesting development, because as a smart window, optical parameters including transmittance change are preferred considering their main function is to regulate the optical transmissivity that enters the building. In this case, based on Table 2, the combination of a-Si:H thin film solar cells and $\mathrm{WO}_{3}$-based electrochromic showed a very good performance compared to the combination of electrochromic and dye-sensitized solar cells when viewed from the value of the transmittance change, although in terms of the energy gains obtained, almost all combinations are still inferior to various photovoltaic technologies which have greater energy efficiency.

Of the TFSC type itself, so far, only TFSC with a-Si: $\mathrm{H}$ material which is silicon-based photovoltaic is the only material that has been reported to be combined with electrochromic. This is because the success of the a-Si: $\mathrm{H}$ thin film material with its high throughput and large area deposition process for solar cells enables a wide application of this type of material. Meanwhile, in terms of the electrochromic coating material itself, several types of materials have been developed in combination which have been reported in several literatures. If it is seen from a comparison with the same PV material, both using DSSC and using TFSC, the electrochromic coating material made of tungsten oxide $\left(\mathrm{WO}_{3}\right)$ is the most superior compared to other materials, which in the literature found viologen material, PProDot-Et2, or polyaniline (PANI) added polystyrene sulfonate (PSS). This illustrates that the development of TFSC with a-Si:H material with electrochromic tungsten oxide $\left(\mathrm{WO}_{3}\right)$ coating has superior potential compared to other combinations. However, the combination shown in Table 2 is only limited to certain electrochromic materials, and in fact there are still many electrochromic materials that have not been reported to have been combined with photovoltaic, although there are other electrochromic materials with more potential.

Some electrochromic materials do have their own uniqueness, with different performances for each material, especially looking at the type of layer electrochromic material which is metal oxide, metal complex, metal alloy and organic molecules. To provide an overview of the performance of each electrochromic material, Table 3 is compiled to describe the various types of electrochromic materials 
used, without being combined with photovoltaic, thus bridging the search for other electrochromic materials with more potential for this combination.

Table 3. Comparison of electrochromic device performance.

\begin{tabular}{|c|c|c|c|c|c|}
\hline Type & EC Material & $\begin{array}{l}\text { Transmittance } \\
\text { Change }(\Delta \mathrm{T})\end{array}$ & $\begin{array}{l}\text { Wavelength } \\
(\lambda)\end{array}$ & $\begin{array}{l}\text { Cycling } \\
\text { stability }\end{array}$ & Reference \\
\hline \multirow{7}{*}{ Metal oxide } & $\begin{array}{l}\mathrm{WO}_{3}: 10 \% \mathrm{Eu}^{3+} \\
\text { with } 0.5 \mathrm{M} \mathrm{H}_{2} \mathrm{SO}_{4}\end{array}$ & $80.7 \%$ & $680 \mathrm{~nm}$ & - & $\begin{array}{l}\text { (Luo et al., } \\
\text { 2017) }\end{array}$ \\
\hline & $\begin{array}{c}1.5 \% \mathrm{Ni}^{-\mathrm{WO}_{3}} \\
\text { with } 0.1 \mathrm{M} \mathrm{LiClO}_{4}-\mathrm{PC}\end{array}$ & $86.0 \%$ & $600 \mathrm{~nm}$ & 5500 & $\begin{array}{l}\text { (Zhou et al., } \\
\text { 2016) }\end{array}$ \\
\hline & $\begin{array}{c}\mathrm{W} / \mathrm{WO}_{3}-\mathrm{V}_{2} \mathrm{O}_{5} \\
\text { with } 1 \mathrm{M} \mathrm{LiClO}_{4}-\mathrm{PC} \\
\end{array}$ & $76.9 \%$ & $560 \mathrm{~nm}$ & - & $\begin{array}{l}\text { (Panagopoulou } \\
\text { et al., 2019) }\end{array}$ \\
\hline & $\begin{array}{c}\mathrm{WO}_{3} \text { film on ITO/PET } \\
\text { with gel electrolyte }\end{array}$ & $49.0 \%$ & $650 \mathrm{~nm}$ & 1000 & $\begin{array}{l}\text { (Eren et al., } \\
\text { 2017) }\end{array}$ \\
\hline & $\begin{array}{c}\text { Glass/ITO/ } / \mathrm{WO}_{3} / \mathrm{Ta}_{2} \mathrm{O}_{5} / \\
\mathrm{NiO} / \mathrm{ITO} / \mathrm{Glass}(\mathrm{ECD}) \\
\text { with } \mathrm{LiClO}_{4} / \mathrm{PC} / \mathrm{DI} \text {-water }\end{array}$ & $50.0 \%$ & $550 \mathrm{~nm}$ & 2000 & $\begin{array}{l}\text { (Chen et al., } \\
\text { 2018) }\end{array}$ \\
\hline & $\begin{array}{c}\mathrm{V}_{2} \mathrm{O}_{5} \\
\text { with } 1 \mathrm{M} \mathrm{LiClO}_{4}-\mathrm{PC}\end{array}$ & $25.0 \%$ & $633 \mathrm{~nm}$ & - & $\begin{array}{l}\text { (Zhi et al., } \\
\text { 2016) }\end{array}$ \\
\hline & $\begin{array}{c}\text { Ti-doped } \mathrm{V}_{2} \mathrm{O}_{5} \\
\text { with } 1 \mathrm{M} \mathrm{LiClO} \mathrm{LiC}_{4}-\mathrm{PC}\end{array}$ & $51.1 \%$ & $415 \mathrm{~nm}$ & 600 & $\begin{array}{l}\text { (Lu et al., } \\
\text { 2013) }\end{array}$ \\
\hline \multirow{8}{*}{ Metal complex } & PB film & $73.0 \%$ & $690 \mathrm{~nm}$ & - & $\begin{array}{l}\text { (Tc et al., } \\
\text { 2016) }\end{array}$ \\
\hline & $\mathrm{PB} / \mathrm{AI}$ & $52.2 \%$ & $670 \mathrm{~nm}$ & - & $\begin{array}{c}\text { (J. Wang et al., } \\
\text { 2014) }\end{array}$ \\
\hline & $\begin{array}{c}\mathrm{Ni}-\mathrm{PBA} \\
\text { with } 1 \mathrm{M} \mathrm{LiClO}_{4}-\mathrm{PC}\end{array}$ & $55.0 \%$ & $400 \mathrm{~nm}$ & - & $\begin{array}{l}\text { (Tc et al., } \\
2016)\end{array}$ \\
\hline & $\begin{array}{c}\mathrm{Cu}-\mathrm{PBA} \\
\text { with } 1 \mathrm{M} \mathrm{LiClO}_{4}-\mathrm{PC} \\
\end{array}$ & $30.0 \%$ & $500 \mathrm{~nm}$ & - & $\begin{array}{l}\text { (Tc et al., } \\
2016)\end{array}$ \\
\hline & $\begin{array}{c}\text { Co-PBA } \\
\text { with } 1 \mathrm{M} \mathrm{LiClO}_{4}-\mathrm{PC} \\
\end{array}$ & $15.0 \%$ & $500 \mathrm{~nm}$ & - & $\begin{array}{c}\text { (Tc et al., } \\
\text { 2016) }\end{array}$ \\
\hline & Fe-polypyridyl complex & $65.0 \%$ & $573 \mathrm{~nm}$ & 1500 & $\begin{array}{c}\text { (Elool Dov et } \\
\text { al., 2017) }\end{array}$ \\
\hline & Ru-polypyridyl complex & $53.0 \%$ & $490 \mathrm{~nm}$ & 50 & $\begin{array}{c}\text { (Elool Dov et } \\
\text { al., 2017) }\end{array}$ \\
\hline & Os-polypyridyl complex & $39.0 \%$ & $514 \mathrm{~nm}$ & 500 & $\begin{array}{c}\text { (Elool Dov et } \\
\text { al., 2017) }\end{array}$ \\
\hline \multirow{4}{*}{ Metal alloy } & $\begin{array}{l}\mathrm{Cu}-\mathrm{Pb} \text { film } \\
\text { with } \mathrm{Cu}^{2+}, \mathrm{Pb}^{2+} / \mathrm{LiClO}^{40}\end{array}$ & $75.0 \%$ & $600 \mathrm{~nm}$ & 5500 & $\begin{array}{c}\text { (Barile et al., } \\
\text { 2017; Co et al., } \\
\text { 2005) }\end{array}$ \\
\hline & $\begin{array}{c}\text { Ag particles film } \\
\text { with } \mathrm{Ag}^{+} / \mathrm{Cu}^{2+} / \mathrm{TBABr}- \\
\text { DMSO }\end{array}$ & $65.0 \%$ & $700 \mathrm{~nm}$ & 50 & $\begin{array}{l}\text { (Tsuboi et al., } \\
\text { 2014) }\end{array}$ \\
\hline & $\begin{array}{c}\mathrm{Bi} \text { film } \\
\mathrm{Bi}^{3+}, \mathrm{Cu}^{2+}, \mathrm{LiBr} \text { in } \\
\text { aqueous solution }\end{array}$ & $65.0 \%$ & $633 \mathrm{~nm}$ & - & $\begin{array}{l}\text { (de Torresi \& } \\
\text { Carlos, 1996; } \\
\text { Ziegler \& } \\
\text { Howard, 1995) }\end{array}$ \\
\hline & $\begin{array}{c}\mathrm{Bi}-\mathrm{Cu} \text { film } \\
\mathrm{Bi}^{3+}, \mathrm{LiBr} \text { in DMSO }\end{array}$ & $59.0 \%$ & - & $1 \times 10^{6}$ & $\begin{array}{c}\text { (Nakashima et } \\
\text { al., 2010) }\end{array}$ \\
\hline \multirow{2}{*}{$\begin{array}{l}\text { Organic } \\
\text { Molecule }\end{array}$} & Viologen in ionic liquid & $65.0 \%$ & $600 \mathrm{~nm}$ & - & $\begin{array}{c}\text { (Vergaz et al., } \\
2009)\end{array}$ \\
\hline & $\begin{array}{c}\text { Bis (dihydroxy propyl) } \\
\text { viologen }\end{array}$ & $50.0 \%$ & $599.5 \mathrm{~nm}$ & 10000 & (S et al., 2019) \\
\hline
\end{tabular}




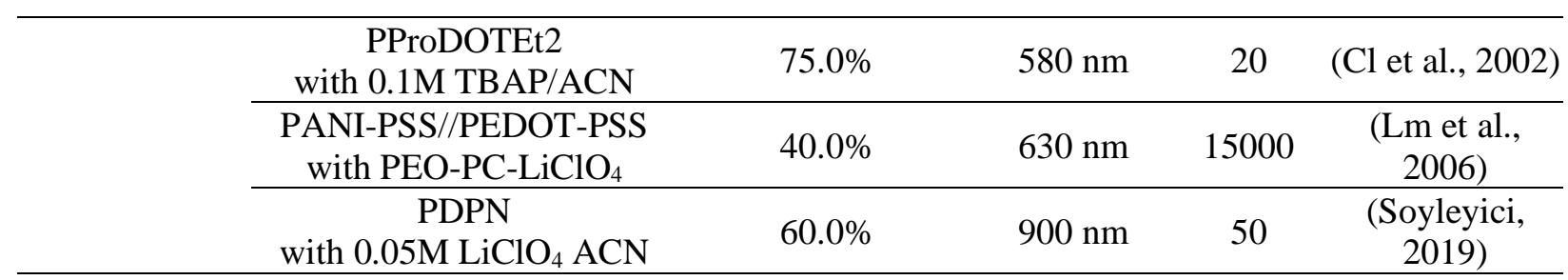

Various electrochromic materials and electrolytes work very varied. Various electrochromic materials reported in the literature have varying values of transmittance change, which represents the ability to change the optical transmissivity of each material. Referring to Table 3, the electrochromic material made from tungsten oxide $\left(\mathrm{WO}_{3}\right)$ still has the best performance so far, the only electrochromic material that achieves a transmittance change above $85 \%$, even though this material is actually the most frequently used material in electrochromic studies (Rai et al., 2020). In addition, the coloration efficiency of $\mathrm{WO}_{3}$ material is also not the best compared to other technologies (Buch et al., 2016).

\section{Design of Electrochromic-Photovoltaic Technology Combination}

Considering the comparison to the literature studies conducted previously, a combination design of electrochromic and photovoltaic technologies was developed. In principle, this configuration simply superimposes a photovoltaic layer and an electrochromic layer on a transparent substrate such as glass or polyethylene terephthalate (PET). This system configuration will use semi-transparent silicon thin film solar cells (Si-TFSC) by adding an electrochromic layer in the form of an electrochromic solution placed between a transparent non-conductive substrate and a Si-TFSC semitransparent substrate. The use of the electrochromic component in the solution form has the advantage of a simpler structure and the structure is formed by a top transparent conductive layer and a bottom transparent conductive layer, which are bonded by a polymer adhesive in the direction facing the electrode layer, and the electrochromic solution is placed between the top and bottom of the bottom transparent conductive layer (Huang et al., 2012; Liu et al., 2020). The system configuration is structured as shown in Figure 3.

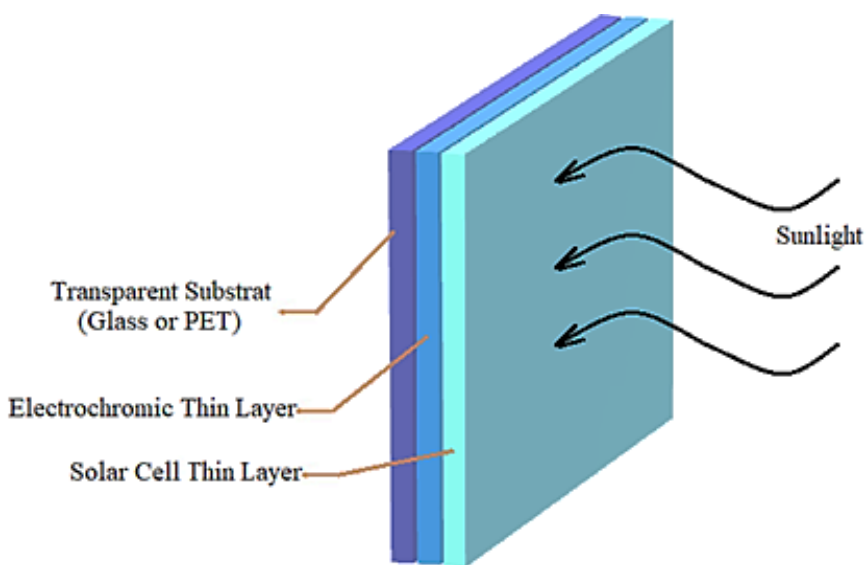

(a)

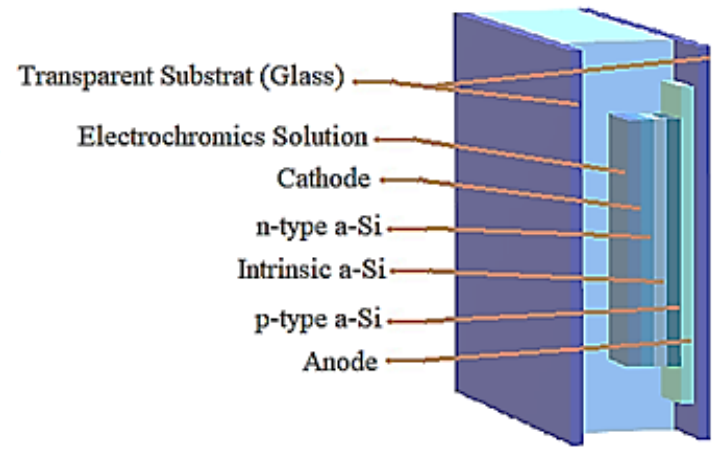

(b)

Figure 3. Configuration design of the thin layer electrochromic-photovoltaic system (a) and Schematic perspective view of the solution type electrochromic-photovoltaic device (b).

As shown in Figure 3 (a), the design of this integrated technology is arranged in the form of a thin stacked film attached to a transparent glass substrate or PET (polyethylene terephthalate) which later becomes the media for the smart window. The use of this transparent substrate is similar to the use of glass in ordinary electrochromic windows pasted on glass or on PET if you want to make a flexible substrate (Ji et al., 2015; Ke et al., 2019; Qu et al., 2015). In this configuration, since both the electrochromic and photovoltaic substrates require an anode and a cathode, the functional parts of the anode and cathode using the transparent conductive oxide (TCO) material of this system can be 
combined, overlapping the anode and cathode of the Si-TFSC photovoltaic. Therefore, the requirement for anode-cathode in an electrochromic configuration can be cut off leaving a portion of the electrochromic solution in the form of a gel (Huang et al., 2012), as shown in Figure 3 (b).

In the proposed configuration, the performance of electrochromic technology still uses the principle of reduction and oxidation reactions (redox). This redox reaction occurs because it is induced by photopotential differences due to sunlight entering the Si-TFSC photovoltaic device. This redox reaction occurs because it is triggered by a current generated by photovoltaics and converted into ionic currents in an electrochromic solution (Huang et al., 2012). Together with the occurrence of this redox reaction, the window will change its coloring state from clear state to dark state, which means the window is on. In other words, when a smart window is exposed to high intensity sunlight, the photovoltaic layer will generate an electronic current and simultaneously trigger the electrochromic layer to change its optical state from clear to opaque. Conversely, if no sunlight enters the photovoltaic device in this configuration, then there is no production of electron holes in the semiconductor layer of the photovoltaic. The absence of photo-potentials in this condition results in the absence of ionic currents in the electrochromic solution so that the redox reaction does not occur. Thus, in the absence of a redox reaction, the electrochromic component does not change its color state. In this condition, the optical state of the window will be in clear state or in off condition. The working scheme on this device is shown in Figure 4.

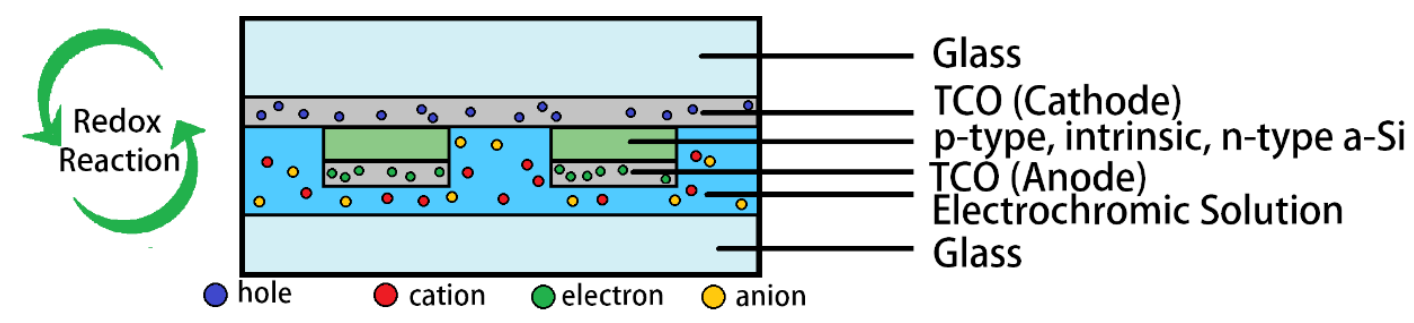

Figure 4. Working principle of solution type electrochromic-photovoltaic device.

In this arrangement, the amorphous photovoltaic layers of the silicon are arranged planar so that the electrochromic gel solution in the center is also planar. The hope is that, with this planar arrangement, the window opacity will be uniform for the entire window area (Huang et al., 2012; Lee \& Di Bartolomeo, 2002). Further, in a larger design, to deal with the problem of voltage decrease in the TCO layer (as anode and cathode) which reduces charging currents and window staining, adding metal busbars on the window edges and installing each panel column with a cell strip connector in series will reduce the loss of resistive energy at the electrodes (Gao et al., 1999). So, the electrochromicphotovoltaic integrated technology design on a larger scale, such as in office buildings, apartments, can still be an option.

\subsection{Optical Performance}

One of the parameters to assess the performance of this electrochromic-photovoltaic integrated device is through its optical parameters. This is because the main function of the smart window is to provide the ability to adjust the optical layer of the window according to its needs to create a comfortable occupancy in it. Therefore, at least two optical states of the smart window, namely when it is opaqued and when it is cleared (Y. Wang et al., 2016; Zakirullin \& Zakirullin, 2020), it is important to check whether the smart window is sufficiently opaque in its opaque state and whether the smart window is sufficiently clear in its clear state, especially with the addition of a photovoltaic layer that is not completely transparent.

In this case, the optical contrast and the spectral response by the electrochromic solution can be illustrated in terms of a graph of the light transmissivity versus time. Referring to Huang et al. (2012), when a device with heptyl viologen and TMPD $\left(\mathrm{N}, \mathrm{N}^{\prime}, \mathrm{N}, \mathrm{N}^{\prime}\right.$-tetramethyl-p-phenylenediamine) solution is illuminated by a solar simulator under $100 \mathrm{~mW} / \mathrm{cm}^{2}$ irradiation, the screen darkens to the lowest 
transmission state in 200 seconds, corresponding to a transmission change $(\Delta \mathrm{T} \%)$ of about $70 \%$ at 590 $\mathrm{nm}$ as shown in Figure 5.

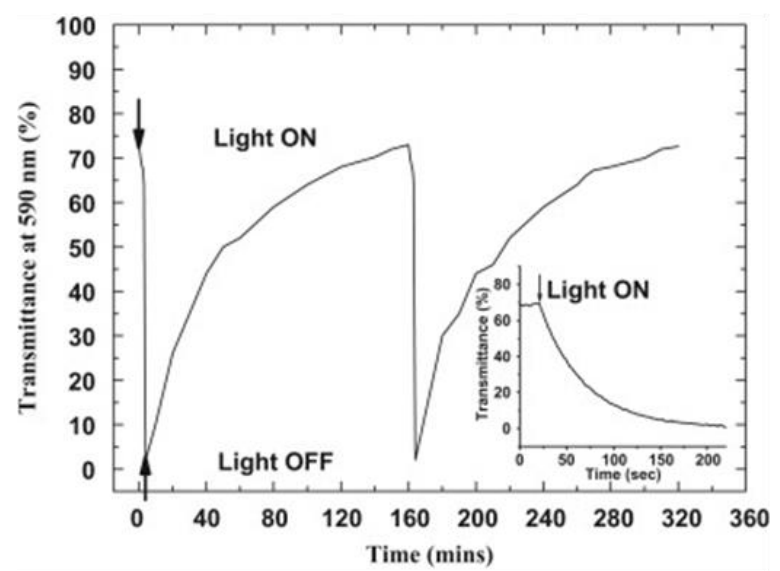

Figure 5. The spectral response of a solution-type electrochromic-photovoltaic device at a wavelength of $590 \mathrm{~nm}$ (Huang et al., 2012).

The window model with the electrochromic-photovoltaic technology developed by Huang et al. (2012) show an optical performance that is not inferior to conventional electrochromic windows, although the presence of photovoltaic components embedded together in this system to some extent affects electrochromic performance. The change in transmissivity $(\Delta \mathrm{T} \%)$ which reaches $70 \%$ in this model with heptyl viologen and TMPD can still be increased by replacing more sophisticated electrochromic materials, one of which is by using a tungsten oxide $\left(\mathrm{WO}_{3}\right)$ nanostructured material in its configuration which has a higher transmittance change, compared to various other electrochromic materials (Buch et al., 2016; Khanapuram et al., 2016; Rai et al., 2020).

\subsection{Energy Saving Potential}

Electrochromic technology as one of the smart window technologies has an energy-saving feature with the presence of an outside heat prevention scheme. Windows with electrochromic technology have the potential to reduce primary energy consumption by $39.5 \%$ compared to conventional glass (Cannavale et al., 2020) with a $60 \%$ reduction in lighting requirements and a $25 \%$ reduction in HVAC load (Rajendran \& Charde, 2018). However, conventional electrochromic windows require an external power supply. The minimum amount of power needed by the system to change different staining states $\left(1-2.5 \mathrm{Wp} / \mathrm{m}^{2}\right)($ Casini, 2014). So, the total net energy consumption is the difference between the energy saved and the power required to activate the electrochromic window. Whereas on the other hand, the use of photovoltaic windows can also help energize the building. The study reported the efficiency of TFSC photovoltaic technology of about $7.8 \%$ for $6 \mu \mathrm{m}$ nanocrystalline films and $8.4 \%$ for $12 \mu \mathrm{m}$ thick nanocrystalline films, with an average transmission range of 20-23\% at $400-700 \mathrm{~nm}$ wavelengths (Husain et al., 2018). How much of the energy saving potential of buildings with electrochromic windows and the potential for energy production by photovoltaic layers is highly dependent on various environmental and building conditions (Nageib et al., 2020).

Given the large potential savings from the two technologies used in the proposed system, it is hoped that the combination of electrochromic and photovoltaic technologies can generate significant energy saving opportunities. Referring to Deb et al. (2001), using a tandem combination of monolithic photovoltaic with electrochromic in nine layers, it was found that $1 \mathrm{kWp}$ of photovoltaic power can remove about $3 \mathrm{Wp}$ of heat from the building envelope through electrochromic performance, while the same $1 \mathrm{kWp}$ of photovoltaic is used for activates an electrochromic-photovoltaic smart window that can reverse $110 \mathrm{kWp}$. Given the more advanced development of electrochromic and photovoltaic technologies over the last decade, energy production through photovoltaic layers should be higher than this, and electrochromic energy consumption can be further saved (Tällberg et al., 2019; Tavares et al., 2014). 


\section{Optimization Strategy}

As one of the components in a building, this adaptive smart window can be optimized to obtain optimal energy saving potential and maximum living comfort. To improve performance, automation or remotecontrol systems can be implanted to provide comfortable living, ease of use, and maximum energy benefits. In its implementation, adaptive smart windows can be integrated with other smart technologies in buildings to automatically control the performance of each of its components in one smart home framework. One application of the control system to this electrochromic-photovoltaic integrated device is shown in the block diagram in Figure 6.

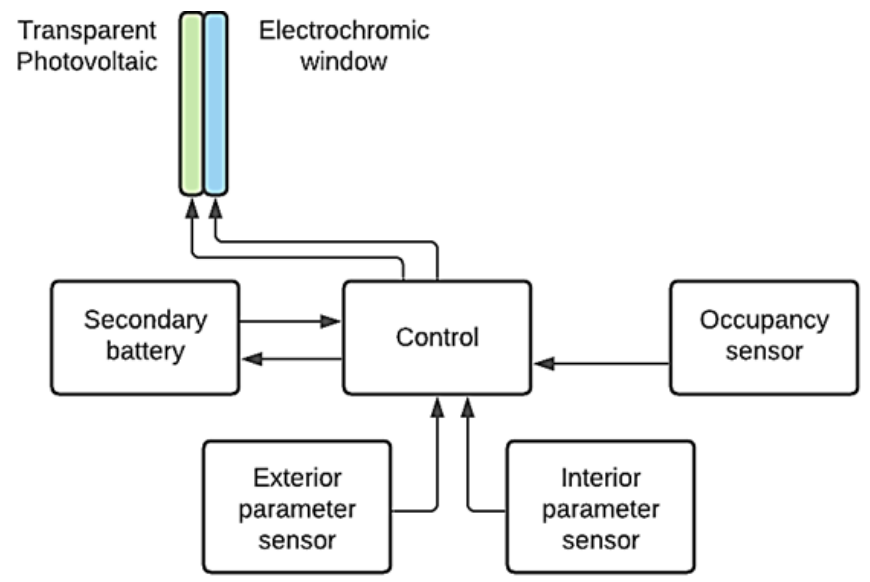

Figure 6. Block diagram of control of integrated electrochromic-photovoltaic devices in buildings.

In this scheme, the control device can be arranged based on a control algorithm according to occupational sensor readings that detect the presence of humans in the room, as well as sensors for interior and exterior parameters of the room, such as sensors for light intensity, temperature, humidity or other parameters that are considered applicable. This control mechanism can be arranged through automatic control or through user control which is displayed through the control device, including one through the control of the interface on the user's gadget. Thus, even though the solar intensity is high and there is a current emerging from the photovoltaic that should be electrochromic turning into an opaque state, the occupancy can set the electrochromic condition to remain in clear state if needed, or if the sensor reads the need for clear state conditions as well.

With the addition of automatic control based on readings of environmental conditions by sensors, the performance of the integrated electrochromic-photovoltaic technology is also expected to increase. This performance increase can be obtained through an increase in optical, thermal performance and energy benefits. In practice, the optical and thermal performance, and in particular the energy benefits obtained, are highly dependent on the environmental conditions in which this adaptive window is used (Ghosh \& Norton, 2018; Nageib et al., 2020).

\section{Conclusions}

A design that integrates electrochromic and photovoltaic devices has been developed by combining an electrochromic solution with a tungsten oxide $\left(\mathrm{WO}_{3}\right)$ material that is disposed of between a transparent non-conductive substrate and a semi-transparent Si-TFSC substrate. The performance of this device is affected by the redox reaction of the electrochromic solution which is triggered by electricity generated by photovoltaics. The combination of the two technologies does not reduce the optical performance of the electrochromic coating but still results in a large change in transmissivity. In its application in buildings, to improve device performance, control systems can be applied by adjusting environmental conditions according to sensor system readings to get better device performance. 


\section{Acknowledgments}

This research did not receive any specific grant from funding agencies in the public, commercial or notfor-profit sectors.

\section{References}

Ahn, K.-S., Yoo, S. J., Kang, M.-S., Lee, J.-W., \& Sung, Y.-E. (2007). Tandem dye-sensitized solar cell-powered electrochromic devices for the photovoltaic-powered smart window. Journal of Power Sources, 168(2), 533-536.

Arifin, Z., Soeparman, S., Denny, W., Purwanto, A., \& Dharmanto, D. (2017). Synthesis, characterisation, and fabrication hollow fibres of zn-doped tio2 for dye-sensitized solar cells. Journal of Engineering Science and Technology, 12, 1227-1239.

Askari, M., Mirzaei Mahmoud Abadi, V., \& Mirhabibi, M. (2015). Types of solar cells and application. American Journal of Optics and Photonics, 3, 2015.

Balakrishnan, A., \& Pattathil, P. (2019). Nanostructured electrochromic materials for smart switchable windows. CRC Press.

Barile, C. J., Slotcavage, D. J., Hou, J., Strand, M. T., Hernandez, T. S., \& McGehee, M. D. (2017). Dynamic windows with neutral color, high contrast, and excellent durability using reversible metal electrodeposition. Joule, 1(1), 133-145.

Bechinger, C., Bullock, J. N., Zhang, J.-G., Tracy, C. E., Benson, D. K., Deb, S. K., \& Branz, H. M. (1998). Low-voltage electrochromic device for photovoltaic-powered smart windows. Journal of Applied Physics, 80(2), 1226.

Buch, V. R., Chawla, A. K., \& Rawal, S. K. (2016). Review on electrochromic property for WO3 thin films using different deposition techniques. Materials Today: Proceedings, 3(6), 1429-1437.

Cai, G., Eh, A. L.-S., Ji, L., \& Lee, P. S. (2017). Recent advances in electrochromic smart fenestration. Advanced Sustainable Systems, 1(12), 1700074.

Cannavale, A., Ayr, U., Fiorito, F., \& Martellotta, F. (2020). Smart electrochromic windows to enhance building energy efficiency and visual comfort. Energies, 13(6), 1449.

Casini, M. (2014). Smart windows for energy efficiency of buildings. Proc. of the Second Intl. Conf. on Advances In Civil, Structural and Environmental Engineering- ACSEE 2014, 10.

Chel, A., \& Kaushik, G. (2018). Renewable energy technologies for sustainable development of energy efficient building. Alexandria Engineering Journal, 57(2), 655-669.

Chen, P.-W., Chang, C.-T., Ali, Md. M., Wu, J.-Y., Li, Y.-C., Chen, M.-H., Jan, D.-J., \& Yuan, C.-T. (2018). Tantalum oxide film deposited by vacuum cathodic arc plasma with improved electrochromic performance. Solar Energy Materials and Solar Cells, 182, 188-195.

Choi, D., Lee, M., Kim, H., Chu, W., Chun, D., Ahn, S.-H., \& Lee, C. S. (2018). Investigation of drydeposited ion storage layers using various oxide particles to enhance electrochromic performance. Solar Energy Materials and Solar Cells, 174, 599-606.

Chopra, K., Paulson, P., \& Dutta, V. (2004). Thin-film solar cells: An overview. Progress in Photovoltaics - PROG PHOTOVOLTAICS, 12, 69-92.

Chwieduk, D. (2003). Towards sustainable-energy buildings. Applied Energy, 76(1), 211-217.

Cl, G., Dm, W., \& Jr, R. (2002). Poly(ProDOT-Et-2): A high-contrast, high-coloration efficiency electrochromic polymer. Macromolecular Rapid Communications, 23(15), 885-889.

Co, A., Ma, N., Ek, K., \& Los, B. (2005). Electrodeposition of lead on ITO electrode: Influence of copper as an additive. Electrochimica Acta, 50(6), 1317-1321.

Corrado, V. (2018). Energy efficiency in buildings research perspectives and trends. Thermal Science, 22, 971-976.

Dao, L. H., \& Nguyen, M. T. (1989). Design and optical modulation of electrochromic windows. Proceedings of the 24th Intersociety Energy Conversion Engineering Conference, 1737-1741.

de Torresi, S. I. C., \& Carlos, I. A. (1996). Optical characterization of bismuth reversible electrodeposition. Journal of Electroanalytical Chemistry, 414(1), 11-16.

Deb, S. K., Lee, S.-H., Edwin Tracy, C., Roland Pitts, J., Gregg, B. A., \& Branz, H. M. (2001). Standalone photovoltaic-powered electrochromic smart window. Electrochimica Acta, 46(13), 21252130 . 
Elool Dov, N., Shankar, S., Cohen, D., Bendikov, T., Rechav, K., Shimon, L. J. W., Lahav, M., \& van der Boom, M. E. (2017). Electrochromic metallo-organic nanoscale films: Fabrication, color range, and devices. Journal of the American Chemical Society, 139(33), 11471-11481.

Eren, E., Karaca, G. Y., Koc, U., Oksuz, L., \& Oksuz, A. U. (2017). Electrochromic characteristics of radio frequency plasma sputtered WO3 thin films onto flexible polyethylene terephthalate substrates. Thin Solid Films, 634, 40-50.

Fernandes, M., \& de Zea Bermudez, V. (2021). Chapter 13-Sol-gel materials for smart electrochromic devices. In S. Das \& S. Dhara (Eds.), Chemical Solution Synthesis for Materials Design and Thin Film Device Applications (pp. 439-475). Elsevier.

Fraas, L. M. (2014). The dream of thin film PV. In L. M. Fraas (Ed.), Low-Cost Solar Electric Power (pp. 73-79). Springer International Publishing.

Gao, W., Lee, S. H., Bullock, J., Xu, Y., Benson, D. K., Morrison, S., \& Branz, H. M. (1999). First a$\mathrm{SiC}: H$ photovoltaic-powered monolithic tandem electrochromic smart window device. Solar Energy Materials and Solar Cells, 59(3), 243-254.

Ghosh, A., \& Norton, B. (2018). Advances in switchable and highly insulating autonomous (selfpowered) glazing systems for adaptive low energy buildings. Renewable Energy, 126, 1003-1031.

Granqvist, C. G. (2014). Electrochromics for smart windows: Oxide-based thin films and devices. Thin Solid Films, 564, 1-38.

Gul, M. S., \& Patidar, S. (2015). Understanding the energy consumption and occupancy of a multipurpose academic building. Energy and Buildings, 87, 155-165.

Heckner, K.-H., \& Kraft, A. (2002). Similarities between electrochromic windows and thin film batteries. Solid State Ionics, 152, 899-905.

Hsu, C.-Y., Lee, K.-M., Huang, J.-H., Justin Thomas, K. R., Lin, J. T., \& Ho, K.-C. (2008). A novel photoelectrochromic device with dual application based on poly(3,4-alkylenedioxythiophene) thin film and an organic dye. Journal of Power Sources, 185(2), 1505-1508.

Huang, L.-M., Hu, C.-W., Liu, H.-C., Hsu, C.-Y., Chen, C.-H., \& Ho, K.-C. (2012). Photovoltaic electrochromic device for solar cell module and self-powered smart glass applications. Solar Energy Materials and Solar Cells, 99, 154-159.

Huang, L.-M., Hu, C.-W., Peng, C.-Y., Su, C.-H., \& Ho, K.-C. (2016). Integration of polyelectrolyte based electrochromic material in printable photovoltaic electrochromic module. Solar Energy Materials and Solar Cells, 145, 69-75.

Husain, A. A. F., Hasan, W. Z. W., Shafie, S., Hamidon, M. N., \& Pandey, S. S. (2018). A review of transparent solar photovoltaic technologies. Renewable and Sustainable Energy Reviews, 94, 779791.

International Energy Agency (IEA). (2019). Perspective from the clean energy transition. The critical role of buildings. International Energy Agency (IEA).

Ji, Y., Qin, C., Niu, H., Sun, L., Jin, Z., \& Bai, X. (2015). Electrochemical and electrochromic behaviors of polyaniline-graphene oxide composites on the glass substrate/Ag nano-film electrodes prepared by vertical target pulsed laser deposition. Dyes and Pigments, 117, 72-82.

Ke, Y., Chen, J., Lin, G., Wang, S., Zhou, Y., Yin, J., Lee, P. S., \& Long, Y. (2019). Smart windows: Electro-, thermo-, mechano-, photochromics, and beyond. Adv. Energy Mater., 38.

Khanapuram, U., Bhat, S. D., Giridhar, V., \& Aryasomayajula, S. (2016). Hybrid electrochromic device with Tungsten oxide (WO3-x) and nafion membrane: Performance with varying tungsten oxide thickness.

Lee, E. S., \& Di Bartolomeo, D. L. (2002). Application issues for large-area electrochromic windows in commercial buildings. Solar Energy Materials and Solar Cells, 71(4), 465-491.

Liu, G., Liu, Y., Luo, N., Sun, Y., \& Li, X. (2020). Preparation for electrochromic devices on PET substrate using screen printing. In P. Zhao, Z. Ye, M. Xu, \& L. Yang (Eds.), Advanced Graphic Communication, Printing and Packaging Technology (pp. 271-277). Springer.

Lm, H., Ch, C., \& Tc, W. (2006). Development and characterization of flexible electrochromic devices based on polyaniline and poly(3,4-ethylenedioxythiophene)-poly(styrene sulfonic acid). Electrochimica Acta, 51(26), 5858-5863.

Lu, Y., Liu, L., Mandler, D., \& Lee, P. S. (2013). High switching speed and coloration efficiency of titanium-doped vanadium oxide thin film electrochromic devices. Journal of Materials Chemistry C, 1(44), 7380-7386. 
Luo, G., Shen, L., Zheng, J., \& Xu, C. (2017). A europium ion doped WO3 film with the bi-functionality of enhanced electrochromic switching and tunable red emission. Journal of Materials Chemistry C, 5(14), 3488-3494.

Mortimer, R. J. (2011). Electrochromic materials. Annual Review of Materials Research, 41, 241-268.

Nageib, A., Elzafarany, A. M., Elhefnawy, M. H., \& Mohamed, F. O. (2020). Using smart glazing for reducing energy consumption on existing office building in hot dry climate. HBRC Journal, 16(1), $157-177$.

Nakashima, M., Ebine, T., Shishikura, M., Hoshino, K., Kawai, K., \& Hatsusaka, K. (2010). Bismuth electrochromic device with high paper-like quality and high performances. ACS Applied Materials \& Interfaces, 2(5), 1471-1482.

Nunes, S. C., Saraiva, S. M., Pereira, R. F. P., Pereira, S., Silva, M. M., Carlos, L. D., Fortunato, E., Ferreira, R. A. S., Rego, R., \& de Zea Bermudez, V. (2019). Sustainable dual-mode smart windows for energy-efficient buildings. ACS Applied Energy Materials, 2(3), 1951-1960.

Panagopoulou, M., Vernardou, D., Koudoumas, E., Tsoukalas, D., \& Raptis, Y. S. (2019). Tungsten doping effect on V2O5 thin film electrochromic performance. Electrochimica Acta, 321, 134743.

Park, M. O. \& J. (2019). Evaluation of building energy and daylight performance according to applying electrochromic and pdcl (polymer dispersed liquid crystal) to office building in South Korea. 227240.

Qu, H., Zhang, H., Li, N., Tong, Z., Wang, J., Zhao, J., \& Li, Y. (2015). A rapid-response electrochromic device with significantly enhanced electrochromic performance. RSC Advances, 5(1), 803-806.

Rai, V., Singh, R. S., Blackwood, D. J., \& Zhili, D. (2020). A review on recent advances in electrochromic devices: A material approach. Advanced Engineering Materials, 22(8), 2000082.

Rajendran, N., \& Charde, M. (2018). Smart technology used for active daylighting techniques mainly based on smart windows, artificial lighting and daylight harvesting. 17.

S, Z., Wd, H., Zs, G., B, J., \& Db, X. (2019). A novel bis(dihydroxypropyl) viologen-based all-in-one electrochromic device with high cycling stability and coloration efficiency. Electrochimica Acta, 298, 533-540.

Salve, R. (2020). State of art of thin film photovoltic cell: A review. International Journal of Scientific Research in Science and Technology, 157-163.

Santa-Nokki, H., Kallioinen, J., \& Korppi-Tommola, J. (2007). A dye-sensitized solar cell driven electrochromic device. Photochemical \& Photobiological Sciences, 6(1), 63-66.

Sbar, N., Podbelski, L., Yang, H. M., \& Pease, B. (2012). Electrochromic dynamic windows for office buildings. International Journal of Sustainable Built Environment, 1, 125-139.

Sharma, S., Jain, K., \& Sharma, A. (2015). Solar cells: In research and applications-A review. Materials Sciences and Applications, 06, 1145-1155.

Soyleyici, H. C. (2019). Electrochromic properties of multifunctional conductive polymer based on naphthalene. Optical Materials, 90, 208-214.

Tällberg, R., Jelle, B. P., Loonen, R., Gao, T., \& Hamdy, M. (2019). Comparison of the energy saving potential of adaptive and controllable smart windows: A state-of-the-art review and simulation studies of thermochromic, photochromic and electrochromic technologies. Solar Energy Materials and Solar Cells, 200, 109828.

Tavares, P. F., Gaspar, A. R., Martins, A. G., \& Frontini, F. (2014). Evaluation of electrochromic windows impact in the energy performance of buildings in Mediterranean climates. Energy Policy, 67, 68-81.

Tc, L., Wh, C., Hy, L., \& Lc, C. (2016). Multicolor electrochromic thin films and devices based on the Prussian blue family nanoparticles. Solar Energy Materials and Solar Cells, 145, 26-34.

Tsuboi, A., Nakamura, K., \& Kobayashi, N. (2014). Multicolor electrochromism showing three Primary color states (cyan-magenta-yellow) based on size- and shape-controlled silver nanoparticles. Chemistry of Materials, 26(22), 6477-6485.

Türkoğlu, S., \& Kardogan, P. O. (2017). The role and importance of energy efficiency for sustainable development of the countries. 3rd International Sustainable Buildings Symposium, 53-60.

Vergaz, R., Barrios, D., Sánchez-Pena, J.-M., Pozo-Gonzalo, C., \& Salsamendi, M. (2009). Relating cyclic voltammetry and impedance analysis in a viologen electrochromic device. Solar Energy Materials and Solar Cells, 12(93), 2125-2132. 
Wang, J., Zhang, L., Yu, L., Jiao, Z., Xie, H., Lou, X. W. D., \& Sun, X. W. (2014). A bi-functional device for self-powered electrochromic window and self-rechargeable transparent battery applications. Nature Communications, 5, 4921.

Wang, Y., Runnerstrom, E. L., \& Milliron, D. J. (2016). Switchable materials for smart windows. Annual Review of Chemical and Biomolecular Engineering, 7(1), 283-304. https://doi.org/10.1146/annurev-chembioeng-080615-034647

Zakirullin, R., \& Zakirullin, R. (2020). Grating optical filters for smart windows: Materials, calculations and prospects. AIMS Materials Science, 7(6), 720-771.

Zhang, L., Wang, B., Li, X., Xu, G., Dou, S., Zhang, X., Chen, X., Zhao, J., Zhang, K., \& Li, Y. (2019). Further understanding of the mechanisms of electrochromic devices with variable infrared emissivity based on polyaniline conducting polymers. Journal of Materials Chemistry C, 7(32), 9878-9891.

Zhi, M., Huang, W., Shi, Q., Peng, B., \& Ran, K. (2016). Enhanced electrochromic performance of vanadium pentoxide/reduced graphene oxide nanocomposite film prepared by the Sol-Gel method. Journal of The Electrochemical Society, 163(10), H891.

Zhou, J., Wei, Y., Luo, G., Zheng, J., \& Xu, C. (2016). Electrochromic properties of vertically aligned $\mathrm{Ni}$-doped WO3 nanostructure films and their application in complementary electrochromic devices. Journal of Materials Chemistry C, 4(8), 1613-1622.

Ziegler, J. P., \& Howard, B. M. (1995). Applications of reversible electrodeposition electrochromic devices. Solar Energy Materials and Solar Cells, 39(2), 317-331. 